\section{B A Institute of \\ YK Business Administration \\ 六下 \\ Karachi \\ Leadership and Ideas for Tomorrow}

\section{Business Review}

Volume 5 Issue 1 January-June 2010

$1-1-2010$

\title{
Bankers perceptions of electronic banking in Pakistan
}

\author{
Ahmad Kaleem \\ Lahore School of Economics, Lahore, Pakistan \\ Saima Ahmad \\ University of Management and Technology, Lahore, Pakistan
}

Follow this and additional works at: https://ir.iba.edu.pk/businessreview

Part of the Corporate Finance Commons, and the Technology and Innovation Commons

(c) $\underset{\mathrm{EY}}{\mathrm{i}}$

This work is licensed under a Creative Commons Attribution 4.0 International License.

\section{Recommended Citation}

Kaleem, A., \& Ahmad, S. (2010). Bankers perceptions of electronic banking in Pakistan. Business Review, 5(1), 131-148. Retrieved from https://doi.org/10.54784/1990-6587.1261

This article is brought to you by iRepository for open access under the Creative Commons Attribution 4.0 License and is available at https://ir.iba.edu.pk/businessreview/vol5/iss1/9. For more information, please contact irepository@iba.edu.pk. 


\title{
ARTICLE
}

\section{Bankers Perceptions of Electronic Banking in Pakistan}

\author{
Ahmad Kaleem \\ Lahore School of Economics, Lahore, Pakistan \\ Saima Ahmad \\ University of Management and Technology, Lahore, Pakistan
}

\begin{abstract}
Electronic distribution channels provide alternatives for faster delivery of banking services to a wider range of customers. E-channels have gained increasing popularity and have attracted the attention of both academics and practitioners. This paper aims to collect bank employees' perceptions of the potential benefits and risks associated with electronic banking in Pakistan. The outcomes may help the management of banks develop effective strategic planning for the future of electronic banking in developing countries like Pakistan.
\end{abstract}

Primary sources were used to collect the data and were analyzed via frequency analysis and mean score analysis. The results suggest that bankers in Pakistan perceive electronic banking as tool for minimizing inconvenience, reducing transaction costs and saving time. Similarly, they believe that electronic banking increases the chances of government access to public data, increases the chances of fraud and that there is a lack of information security. Bank personnel profiles were further analyzed in relation to their perceptions to identify different segments among the target respondents.

The results show that public bank employees who have professional degrees consider 'minimizing transaction costs' and 'reduction in HR requirements' as the most and the least important benefits of electronic banking respectively. Private bank employees who have masters or bachelor degrees, and less than 10 years experience, perceive 'time saving and minimizing inconvenience' as the major benefits of electronic banking. However they did not consider 'reducing the risk of carrying cash' as an important benefit.

Branch managers who are directly responsible for the operations viewed 'facilitates quick response' as the most important benefit of electronic banking. Lastly, private bank employees who hold masters degrees and have more than 10 years working experience did not perceive 'improvement in service quality' as an important benefit. Interestingly, bankers in all segments considered 'government access to data' as the biggest risk associated to electronic banking. 
Keywords: Electronic Banking, Bankers, Pakistan, Benefits, Risks

\section{Introduction}

The rapid advancement in electronic distribution channels has produced tremendous changes in the financial industry in recent years, with an increasing rate of change in technology, competition among players and consumer needs (). Increasing competition among banks and from non-bank financial institutions also raises concerns as to why some people adopt one distributional channel and others do not, and identifying the factors that may influence this decision is vital for service providers. New services are difficult to evaluate where the quality of trustworthiness dominates (Patricio, 2003). It is also important to study the impact of technology based transactions on bankers' perceptions and behaviour (Lymperopoulos, and Chaniotakis, 2004). IT-based distribution channels reduce personal contact between the service providers and the customers, which inevitably leads to a complete transformation of traditional bank-customers relationships (Barnes and Howlett, 1998).

This paper first reviews the existing literature on electronic banking and then examines bankers' perceptions towards electronic banking in Pakistan. It also links personal characteristics of the respondents (work experience, position in the bank, qualification and the type of bank they are serving, i.e. private banks, privatized banks and public banks) with their perceptions of electronic banking. This analysis of data helps to identify the views of different segments of employee and to suggest effective strategic planning for the future of electronic banking in developing countries like Pakistan.

\section{Objectives}

To find the critical benefits that bankers expect for their customers when using electronic banking.

To examine bankers' perceptions of the risk associated to electronic banking. To explore whether bankers' perceptions are linked with their work experience, their position in the branch hierarchy, their educational qualifications or the type of bank they work for (private, privatized and public).

To review the existing literature, discuss results and their implications that provide insights for researchers and banks interested in electronic distribution channels.

\section{Commercial Banking in Pakistan}

Before 1990 public banks dominated the Pakistani financial market. In 1991, two smaller banks, the Muslim Commercial Bank and the Allied Bank, were privatized as part of the government's general program of economic liberalization and the privatization 
of state enterprises. The government also instructed the State Bank of Pakistan (SBP) to approve proposals for the establishment of commercial banks in the private sector. Since then, the government has continuously advocated the privatization of the banking sector and the setting up of new private and foreign banks. The recent acquisitions of a local Union Bank by Standard Chartered Bank and Prime Bank by ABN Amro Bank indicate foreign interest in the domestic financial market. According to the SBP Annual Report (2006), there were thirty five commercial banks operating in the country, which included sixteen private banks (with 797 branches), eleven foreign banks (with 82 branches), four privatized banks (with 4,141 branches) and four public banks (with 1,543 branches).

\section{Electronic Banking in Pakistan}

Electronic banking is the latest in the series of technological wonders of the recent past. ATMs, TeleBanking, Internet Banking, Credit Cards and Debit Cards have emerged as effective delivery channels for traditional banking products. In Pakistan, foreign banks took the lead by introducing ATMs and credit cards in the mid 1990s, and domestic banks followed in the late 1990s. The SBP Annual Report (2003: p. 110) explained this delayed entry in electronic banking largely by regulatory hurdles, higher start up costs, on-going banking sector reforms and lack of technical skills.

The Government of Pakistan further promoted electronic banking with the promulgation of the Electronic Transaction Ordinance 2002. This landmark step provided legal recognition of digital signatures and documentation reducing the risks associated with the use of electronic media in business. At present, almost all commercial banks in Pakistan have setup their own ATM networks, issue debit and credit cards and have joined one of the two operating ATM Switch Networks.

According to Kolachi, (2006) Pakistani banks provides the following online banking services and products. (1) Inquiry: Account statement inquiry, Account balance inquiry, Check statement inquiry, Fixed deposit inquiry (2) Payment: Transfer of funds, Credit cards payments, Direct payments, Utility bills payments (3) Request: Chequebook requests, Stop payment requests, Demand draft requests, New fixed deposit requests (4) Download: Customer profile, Statement download, Other information and guidelines download. Table 1 provides an overview of the development of electronic banking in Pakistan. It shows that the number of online branches, ATM networks, and debit and credit card holders have increased sharply since the year 2000. The SBP Annual Report (2005, p. 111) shows that domestic banks are the major supplier of ATM facilities while foreign banks, mainly Citibank and Standard Chartered, dominate the credit card business in Pakistan and account for over 95 per cent of the total amount transactions. 
Table 1

Electronic Banking Statistics in Pakistan

\begin{tabular}{|l|c|c|c|c|c|c|c|}
\hline Item & $\mathbf{2 0 0 0}$ & $\mathbf{2 0 0 1}$ & $\mathbf{2 0 0 2}$ & $\mathbf{2 0 0 3}$ & $\mathbf{2 0 0 4}$ & $\mathbf{2 0 0 5}$ & $\begin{array}{c}\text { June } \\
\mathbf{2 0 0 6}\end{array}$ \\
\hline No of online branches & 322 & 450 & 777 & 1,581 & 2,475 & 3,265 & 3,555 \\
\hline No of ATMs & 206 & 259 & 399 & 552 & 786 & 1,217 & 1,612 \\
\hline $\begin{array}{l}\text { No of Debit Cards } \\
\text { Holders (000) }\end{array}$ & 240 & 415 & 736 & 1,257 & 1,874 & 4,257 & 4,999 \\
\hline $\begin{array}{l}\text { No of Credit } \\
\text { Cards Holders (000) }\end{array}$ & 217 & 292 & 369 & 397 & 808 & 1,257 & 1,512 \\
\hline
\end{tabular}

(Source; SBP Annual Report, 2006, p. 65)

\section{Literature Review}

Bankers' and consumers' perceptions of the benefits of electronic banking have attracted the attention of many researchers, especially in recent years. Berry (1984) stressed that employees must be viewed by the management as 'internal customers'. Maintenance of high level of employee satisfaction and retention is important if banks are to achieve high levels of customer satisfaction and retention.

Bowen et al., (1999) concluded that when front-line employees feel they have been treated fairly, they are more likely to treat the customers fairly. In a subsequent study of the relationship between bank employees and customers, Bowen et al., (2000) found that employee morale is strongly related to customer satisfaction; that is, when bank customers perceive front-line employees are happy with their work, bank customers are more likely to be satisfied with the service they receive.

Banks normally assign their managers responsibility for the promotion of the use of electronic channels to customers (Lymperopoulos, and Chaniotakis, 2004). Their input as delivery staff is important. It is also the manager's responsibility to ensure that branch staff are professional, well-trained and knowledgeable about the range of services provided by the bank (Moutinho, 1997).

Moutinho and Phillips (2002) found that Scottish bank managers considered efficiency and enhancement of customer service to be two perceived advantages of Internet banking. Similarly, ) highlighted faster, easier, and more reliable service for customers, and improvement of the bank's competitive position to be the most important drivers of online banking among bank and IT managers in Kuwait.

\section{Benefits of Electronic Banking}

Thornton and White (2001) compared several electronic distribution channels available for banks in US and concluded that customer orientation - towards convenience, 
service, technology, change, knowledge about computing and the Internet - affected the usage of different channels.

Howcroft et al., (2002) found that the most important factors encouraging consumers to use online banking are lower fees followed by reducing paper work and human error, which subsequently minimize disputes (Kiang et al., 2000).

Byers and Lederer, (2001) concluded that it was changing consumer attitudes rather than bank cost structures that determines the changes in distribution channels; they added that virtual banks can only be profitable when the segment that prefers electronic media is approximately twice the size of the segment preferring street banks.

Convenience of conducting banking outside the branch official opening hours has been found significant in cases of adoption. Banks provide customers convenient, inexpensive access to the bank 24 hours a day and seven days a week. Moutinho et al., (1997) pointed out that each ATM could carry out the same, essentially routine, transactions as do human tellers in branch offices, but at half the cost and with a four-to-one advantage in productivity.

Gerrard and Cunningham (2003) found a positive correlation between convenience and online banking and remarked that a primary benefit for the bank is cost saving and for the consumers a primary benefits is convenience. Multi-functionality of an IT based services may be another feature that satisfies customer needs (Gerson, 1998).

A reduction in the percentage of customers visiting banks with an increase in alternative channels of distribution will also minimize the queues in the branches (Thornton and White, 2001). Increased availability and accessibility of more self-service distribution channels helps bank administration in reducing the expensive branch network and its associate staff overheads. Bank employees and office space that are released in this way may be used for some other profitable ventures (Birch and Young, 1997). This ultimately leads towards improved customer satisfaction and the institution's bottom line (Thornton and White, 2001).

Internet banking also increases competition within the banking system and also from non-bank financial institution (ECB, 1999). The Internet increases the power of the customer to make price comparisons across suppliers quickly and easily. As a consequence, this pushes prices and margins downward (Devlin, 1995).

Institutional encouragement of the use of IT-based services and IT service fees are another important dimension (Zhu at al., 2002). Cantrell (1997) conducted a banking survey in the US and found that increases in service fees were one of the main driving forces behind the move of some large bank customers to smaller community banks. 
Yakhlef (2001) pointed out that banks are responding to the Internet differently, and that those which see the Internet as a complement and substitute to traditional channels achieved better communication and interactivity with customers. Robinson (2000) argued that the online banking extends the relationship with the customers through providing financial services right into the home or office of customers. The banks may also enjoy the benefits in terms of increased customers loyalty and satisfaction (Oumlil and Williams, 2000).

Nancy et al. (2001) viewed the same situation differently and argued that customers like to interact with humans rather than machines. They found more possibilities for asking questions and believe that bank clerks are less prone to errors. It is thus essential that any face-to-face transactions are carried out efficiently and courteously. This increases the possibility of selling the customer another service that they need and also promotes a good image and enhances customer loyalty (Moutinho et al., (1997).

Polatoglu and Ekin (2001) found that low levels of email usage and a preference for doing over-the-counter transactions at bank branches are the main reasons for not using e-banking in Turkey. The opportunity to conduct a trial may help to convince reluctant customers (Black et al., 2001).

Boon and Ming (2003) concluded that banks in Malaysia should concentrate on enhancing their operation and product management through a mixture of branch banking and e-channels, like ATMs, phone banking and PC banking.

\section{Risks Associated with Electronic Banking}

Although, electronic banking provides many opportunities for the banks, it is also the case that the current banking services provided through Internet are limited due to security concerns, complexity and technological problems (Sathye, 1999: Mols, 1999)

Hewer and Howcroft (1999) used the term trust to describe a measure of risk. Suganthi et al., (2001) viewed risk in the context of security concerns and risk in the context of trust in one's bank. Finally, a number of studies found trust and perceived risks have a significant positive influence on commitment (Bhattacherjee, 2002; Mukherjee and Nath, 2003) and ultimately leads towards overall satisfaction (Rexha et al., 2003).

Reputation of a service provider is another important factor affecting trust. Doney and Cannon (1997) defined reputation as the extent to which customers believe a supplier or service provider is honest and concerned about its customers. Tyler and Stanley (1999) argued that banks can build close and long lasting relationships with customers only if trust, commitment, honesty and cooperation is developed between them. 
Nancy et al.'s (2001) study found that customers' complain about computer logon times which are usually longer than making a telephone call. In addition, respondents felt that they have to check and recheck the forms filled in online, as they are worried about making mistakes.

Frequent slow response time and delay of service delivery causes customers to be unsure that the transaction has been completed (Jun and Cai, 2001). Min and Galle (1999) found the disruption of information access to be a common factor related to unwillingness to use Internet channels for commerce.

Liao and Cheung (2002) found that individual expectations regarding accuracy, security, transaction speed, user friendliness, user involvement and convenience are the most important attributes in the perceived usefulness of Internet-based e-retail banking. Confidentiality of consumer data is another important concern in the adoption of online banking (Gerrard and Cunningham, 2003). Customers fear that someone will have unlimited access to their personal financial information.

White and Nteli (2004) conducted a study that focused on why the increase in Internet users in the UK had not been paralleled by increases in Internet usage for banking purposes. Their results showed that customers still have concerns with the security and the safety aspects of the Internet.

Lack of specific laws to govern Internet banking is another important concern for both the bankers and the customers. This relates to issues such as unfair and deceptive trade practice by the supplier and unauthorized access by hackers. Larpsiri et al., (2002) argued that it is not clear whether electronic documents and records are acceptable as sufficient evidence of transactions. They also pointed out that the jurisdiction of the courts and dispute resolution procedures in the case of using the Internet for commercial purposes are important concerns. Disputes can arise from many sources. For instance, websites are not a branch of the bank. It is difficult for the court to define the location of the branch and decide whether they have jurisdiction (Rotchanakitumnuai and Speece, 2003).

Other risks associated to electronic banking are job losses, lack of opportunities to socialize and the development of a lazy society (Black at al., 2001).

\section{Methodology}

The present study used a survey that was designed and conducted in Lahore, where almost twenty per cent of all bank branches in Pakistan are located. 15 major commercial banks were selected, representing more than 90 per cent of the whole banking system in terms of total assets. The selection criterion was that each bank must have a minimum of five branches in Lahore City. The survey selected every tenth branch at random and addresses of the branches were downloaded from the official websites of the respective banks. 
A specifically designed questionnaire was used as a tool, and banks employees were requested to complete this during office hours. Trained students under the supervision of a lead researcher distributed and collected the questionnaires. In each branch at least three branch employees were requested to fill in the questionnaire, at least one at each of the levels of officer, manager and executive. Some of the employees refused to take part in the research, especially those from privatized banks. Similarly, some incomplete questionnaires were rejected and the branches were subsequently excluded from the list. Overall 207 questionnaires were selected for the purpose of analysis.

The questionnaire was in English. Participants were asked to express the level of their agreement with 18 attributes/factors identified earlier from the literature. 9 attributes covered the perceptions of bank employees towards the benefits/advantages of electronic banking, while the remaining attributes covered the risk associated with electronic banking. In answering the questions, respondents were assured of the confidentiality of their responses and their names were not included on the questionnaire.

A five point Likert scale was used to measure all the statements $(1=$ strongly disagree to $5=$ strongly agree). Moreover, respondents' profiles (work experience, position, qualification and type of bank they are currently serving) were also quantified in order to study potential links between the bankers' perceptions towards electronic banking with their personal characteristics. Before the field work, a pilot study with ten branch employees was conducted in order to refine the questions. Finally, data was analyzed via frequency analysis and mean score analysis.

\section{Results and Discussions}

Table 2

Profile of Respondents

\begin{tabular}{|l|l|cc|}
\hline & & $\mathbf{N}=\mathbf{2 0 7}$ & $\mathbf{\%}$ \\
\hline Working Experience & $1-5$ years & 104 & $50.20 \%$ \\
& 6-10 years & 62 & $30.00 \%$ \\
\hline & more than 10 years & 41 & $19.80 \%$ \\
\hline & & & \\
\hline Position & Executives & 70 & $33.80 \%$ \\
\hline & Managers & 44 & $21.40 \%$ \\
\hline & Officers & 93 & $44.90 \%$ \\
\hline Qualification & & \multicolumn{2}{|c|}{} \\
\hline & M.A (16 years of education) & 106 & $51.20 \%$ \\
\hline & B.A (14 years of education) & 34 & $16.40 \%$ \\
\hline & Professional Degree (MBA, C.A etc.) & 67 & $32.40 \%$ \\
\hline & & 151 & $72.90 \%$ \\
\hline & Private Banks & 31 & $15.10 \%$ \\
\hline & Privatized Banks & 25 & $12.10 \%$ \\
\hline
\end{tabular}


The personal characteristics of the sample (bankers) are outlined in Table 1. The data shows that $50.20 \%$ and $30.00 \%$ of the respondents hold work experiences between 1 to 5 years and between 6 to 10 years respectively. The position based classification of bankers includes Executive (33.80\%), Manager $(21.40 \%)$ and Officer (44.90\%). 106 bankers held Master degrees; 34 bankers held Bachelor degrees while another 67 bankers held professional degrees. The data also shows that $72.90 \%$ of the respondents were currently attached to private banks while $15.10 \%$ and $12.10 \%$ were working with privatized (public banks which have been privatized along with management control) and public banks respectively.

Table 3

\section{Bankers' Perceptions of the Benefits/Advantages of Electronic Banking}

\begin{tabular}{|ll|c|c}
\multicolumn{1}{|c|}{ Statements } & Mean & Rank \\
\hline 1. & Electronic banking minimizes the cost of transactions & 4.42 & 2 \\
\hline 2. & Electronic banking saves time & 4.41 & 3 \\
3. & Electronic banking minimizes inconvenience & 4.44 & 1 \\
\hline 4. & Electronic banking provides up-to-date information & 4.33 & 6 \\
\hline 5. & Electronic banking increases operational efficiency & 4.34 & 5 \\
\hline 6. & Electronic banking reduces HR requirements & 4.19 & 9 \\
\hline 7. & Electronic banking facilitates quick responses & 4.34 & 4 \\
\hline 8. & Electronic banking improves service quality & 4.23 & 8 \\
\hline 9. & Electronic banking minimizes the risk of carrying cash & 4.26 & 7 \\
\hline
\end{tabular}

Table 3 shows the mean scores of bankers' perceptions of the benefits of electronic banking. Table 3 shows that the statements, "Electronic banking minimizes inconvenience", "Electronic banking minimizes the cost of transactions" and "Electronic banking saves time" appear with the highest mean scores of 4.44, 4.42 and 4.41. The outcomes are similar to those of earlier studies made by Moutinho et al., (1997), Thornton and White (2001), Howcroft et al., (2002) and Gerrard and Cunnigham (2003).

The bankers give average importance to the statements, "Electronic banking facilitates quick responses" (4.34), "Electronic banking increases operational efficiency" (4.34) and "Electronic banking provides up-to-date information" (4.33). These outcomes are contrary to the findings of Moutinho and Phillips (2002) in case of UK and Aladwani (2001) in case of Kuwait, where the managers gave the highest priority to faster, easier and reliable IT services for customers.

The statements "Electronic banking reduces HR requirements" (4.19) and "Electronic banking improves service quality" (4.23) had the lowest mean scores. These findings are the opposite of those found by Birch and Young (1997) who found reductions in branches and associated staff with the introduction of Internet banking. The low mean 
score for a reduction in HR requirements was associated with the low level and recent penetration of electronic banking in the country, as highlighted in Table 1. Boon and Ming (2003) suggested in case of Malaysia that the top management of the banks should enhance their operations through a mixture of branch banking and e-channels like ATMs, phone banking and PC banking.

Table 4

Bankers' Perceptions of the Risks Associated with Electronic Banking

\begin{tabular}{|c|l|c|c|}
\hline & \multicolumn{1}{|c|}{ Statements } & Mean & Rank \\
\hline 1. & Electronic banking has the chance of data loss & 1.94 & 7 \\
\hline 2. & Electronic banking has the chance of fraud & 2.48 & 2 \\
\hline 3. & Electronic banking has the chance of government access & 3.83 & 1 \\
\hline 4. & Electronic banking lacks information security & 2.17 & 3 \\
\hline 5. & Electronic banking charge a high cost for services & 1.79 & 9 \\
\hline 6. & Electronic banking has many legal and security issues & 1.93 & 8 \\
\hline 7. & Electronic banking needs expertise and training & 1.98 & 4 \\
\hline 8. & Electronic banking has inadequate information on the website & 1.95 & 5 \\
\hline 9. & Electronic banking has less operational reliability & 1.95 & 6 \\
\hline
\end{tabular}

Table 4 shows the bankers' perceptions of the risks associated with electronic banking. The results show that bankers agreed with the statement "Electronic banking has the chance of government access" which appears with the highest mean score of 3.83 , followed by the statements "Electronic banking has the chance of fraud" (2.48) and "Electronic banking lacks information security" (2.17).

These findings are similar to those of Gerrard and Cunningham (2003) who, in case of Singapore, emphasized that the confidentiality of consumer data is an important concern in the adoption of the online banking. Customers fear that someone will have unlimited access to their personal financial information. Further, steps should be taken to develop trust among banks employees, first towards the issues of information security and the chances of fraud. A number of studies found trust and perceived risk have a significant positive influence on commitment (Bhattacherjee, 2002; Mukherjee and Nath, 2003), White and Nteli (2004). A decrease in employee morale has a negative impact on customer satisfaction (Bowen et al., 2000).

Table 4 shows that bankers do not agree with the statements "Electronic banking charges a high cost for services" (1.79) and "Electronic banking has many legal and security issues" (1.93). The statement "Electronic banking charges a high cost for services" needs further investigation. Contrell (1997) found, in the case of the United States, a movement of large bank customers towards the smaller community banks, motivated by high service fees. Lastly, bankers assigned less weight to 'legal and security issues', and this may be due to the legal recognition of digital signatures after the issuance of Electronic Transaction Ordinance (2002). 
The analysis was developed further, where mean scores were analyzed by using various dimensions (e.g. experience, position held, qualification and type of bank). In order to accentuate the dimensions expressed by each factor, only the questions with the highest and lowest mean scores are discussed. Table 5 presents the bankers' perceptions of the benefits while Table 6 covers banker perceptions of the risks associated with electronic banking.

Table 5

Most and Least Desired Benefits of Electronic Banking in terms of Mean Scores

\begin{tabular}{|c|c|c|c|c|c|c|c|c|c|}
\hline & Q1 & $\mathbf{Q 2}$ & Q3 & Q4 & Q5 & Q6 & Q7 & Q8 & Q9 \\
\hline \multicolumn{10}{|l|}{ EXPERIENCE } \\
\hline Between 1 and 5 years & 4.44 & 4.43 & $4.46 * *$ & 4.35 & 4.31 & $4.09 *$ & 4.30 & 4.19 & 4.26 \\
\hline $\begin{array}{l}\text { Between } 6 \text { and } 10 \\
\text { years }\end{array}$ & 4.39 & 4.31 & $4.45 * *$ & 4.31 & 4.37 & $4.24 *$ & 4.31 & 4.31 & $4.24 *$ \\
\hline More than 10 years & 4.39 & 4.46 & 4.39 & 4.34 & 4.37 & 4.37 & $4.51 * *$ & $4.22 *$ & 4.27 \\
\hline \multicolumn{10}{|l|}{ POSITION HELD } \\
\hline Executives & 4.39 & 4.39 & $4.40 * *$ & 4.33 & $4.40 * *$ & 4.11 & 4.30 & 4.23 & 4.26 \\
\hline Managers & 4.41 & 4.45 & 4.45 & 4.27 & 4.32 & 4.18 & $4.50 * *$ & 4.25 & 4.25 \\
\hline Officers & 4.44 & 4.40 & $4.47 * *$ & 4.37 & 4.30 & 4.25 & 4.30 & $4.23 \%$ & 4.26 \\
\hline \multicolumn{10}{|l|}{ QUALIFICATION } \\
\hline M.A (16 Years) & 4.40 & 4.43 & $4.44 * *$ & 4.37 & 4.38 & 4.26 & 4.32 & $4.22 *$ & 4.25 \\
\hline B.A (14 Years) & 4.38 & 4.35 & $4.53 * *$ & 4.35 & $4.24 *$ & 4.29 & 4.50 & 4.38 & 4.41 \\
\hline Professional Degree & $4.46 * *$ & 4.39 & 4.40 & 4.27 & 4.33 & $4.01 *$ & 4.30 & 4.18 & 4.19 \\
\hline \multicolumn{10}{|l|}{ BANK TYPE } \\
\hline Private Banks & 4.40 & 4.44 & $4.44 * *$ & 4.33 & 4.36 & 4.17 & 4.32 & $4.19 *$ & 4.26 \\
\hline Privatized Banks & 4.39 & 4.45 & $4.45 * *$ & 4.42 & 4.32 & 4.42 & 4.44 & 4.32 & $4.26 *$ \\
\hline Public Banks & $4.56 * *$ & 4.16 & 4.44 & 4.24 & 4.24 & $4.00 *$ & 4.32 & 4.36 & 4.24 \\
\hline
\end{tabular}

** Most Expected Benefits, * Least Expected Benefits

Table 5 shows that bank employees who have between 1 and 5 years work experience and between 6 and 9 years believe 'minimizes inconvenience' is the most important benefit of electronic banking. The respondents are probably young and more familiar with the technological advantages. Young staff also perceives that electronic banking will not 'reduce human resource requirements'. Mature staff who more than 10 years of working experience can be assumed to be more aware of the bank distribution strategies. They, in contrast to young staff, believe that 'facilitates quick responses' is the main advantage of electronic banking. However, mature staff disagrees with the statement "Electronic banking improves service quality".

In terms of position held, Executives who sit at the top of the branch hierarchy and who have better access to corporate information believe that electronic banking 'minimizes inconvenience and increases the overall operational efficiency'. Branch Managers who are directly responsible for the branch operations believe that 'quick response' is the main advantage of electronic banking. Both Executives and Managers disagree that there will be a 'reduction of HR requirements' as the main advantage of 
electronic banking. Further, Officer Employees who are normally young and have limited exposure to bank customer relations believe that 'minimizes inconvenience' is the most important benefit. Officers also believe that electronic banking overall do not 'improve the service quality'. The findings are quite similar to those above mentioned.

Analysis by "qualification" shows that employees who have Masters and Bachelors degrees perceive 'minimizes inconvenience' as the main advantage of electronic banking as compared to professional degree holders (such as MBA's and Chartered Accountants) who give more importance to 'minimizes transaction costs'. Professional degree holders attach least importance 'reduces HR requirements' while Masters and Bachelor degree holders do not consider 'improves service quality and improves operational efficiency' to be important benefits of electronic banking.

Lastly, employees of private and privatized banks consider 'time saving and minimizes inconvenience' to be important benefits while employees of public banks give more weight to 'minimizes transaction costs'. The difference in attitude can be accounted for in terms of the different nature of businesses. Private Banks are normally considered to be more innovative and flexible as compared to public banks. Further, public banks normally serve government and semi-government employees/entities where cost is considered the most important element as compared to private banks which focus on efficient customer service for rich individuals and corporate clients.

Summarizing Table 5 it can be concluded that professional degree holders sitting in public banks consider 'minimizes transaction cost' to be an important benefit. Masters and Bachelor degree holders who have between 1 and 5 and between 6 and 10 years of work experience and are currently serving in private and privatized banks perceive 'time saving and minimizes inconvenience' to be the major benefits of electronic banking. Managers who are directly responsible for operations consider 'facilitates quick responses' to be the most important aspect. Further, Managers and Executives who have professional degrees and currently work with public banks do not consider electronic banking as threat to current HR requirements. Employees of privatized banks who have between 6 and 10 years work experience do not consider 'reduces risk of carrying cash' to be an important benefit of electronic banking. 
Table 6

Most and Least Desired Risks Associated with Electronic Banking in terms of Mean Scores

\begin{tabular}{|c|c|c|c|c|c|c|c|c|c|}
\hline & Q1 & $\mathbf{Q 2}$ & Q3 & Q4 & Q5 & Q6 & Q7 & Q8 & Q9 \\
\hline \multicolumn{10}{|l|}{ EXPERIENCE } \\
\hline Between 1 and 5 years & 1.99 & 2.41 & $3.88 * *$ & 2.19 & $1.80 *$ & 1.88 & 1.94 & 1.92 & 1.91 \\
\hline $\begin{array}{l}\text { Between } 6 \text { and } 10 \\
\text { years }\end{array}$ & 1.90 & 2.71 & $3.85 * *$ & 2.11 & $1.87 *$ & 1.98 & 2.06 & 1.97 & 2.03 \\
\hline More than 10 years & 1.85 & 2.32 & $3.68 * *$ & 2.20 & $1.63 *$ & 1.98 & 1.95 & 1.98 & 1.90 \\
\hline \multicolumn{10}{|l|}{ POSITION HELD } \\
\hline Executives & $1.77 *$ & 2.31 & $3.89 * *$ & 2.10 & 1.84 & 1.87 & 1.93 & 1.89 & 1.91 \\
\hline Managers & 1.95 & 2.70 & $3.75 * *$ & 2.25 & $1.66 *$ & 1.98 & 2.09 & 1.98 & 1.91 \\
\hline Officers & 2.05 & 2.51 & $3.83 * *$ & 2.18 & $1.81 *$ & 1.95 & 1.97 & 1.98 & 1.99 \\
\hline \multicolumn{10}{|l|}{ QUALIFICATION } \\
\hline M.A (16 Years) & 1.97 & 2.40 & $3.71 * *$ & 2.13 & $1.83 *$ & 1.87 & 1.92 & 1.93 & 1.92 \\
\hline B.A (14 Years) & 2.00 & 2.35 & $3.76 * *$ & 2.18 & $1.94 *$ & 2.06 & 2.09 & 1.94 & 2.06 \\
\hline Professional Degree & 1.85 & 2.69 & $4.06 * *$ & 2.22 & $1.64 *$ & 1.96 & 2.01 & 1.97 & 1.94 \\
\hline \multicolumn{10}{|l|}{ BANK TYPE } \\
\hline Private Banks & 1.99 & 2.54 & $3.85 * *$ & 2.20 & $1.79 *$ & 1.93 & 1.99 & 1.93 & 1.95 \\
\hline Privatized Banks & $1.84 *$ & 2.52 & $3.71 * *$ & 2.26 & 1.97 & 2.03 & 2.13 & 2.16 & 2.13 \\
\hline Public Banks & 1.72 & 2.12 & $3.84 * *$ & 1.88 & $1.56 *$ & 1.80 & 1.72 & 1.76 & 1.72 \\
\hline
\end{tabular}

** Most Expected Risk, * Least Expected Risk

Lastly, Officers from private banks who hold Master degrees and have more than 10 years working experience assign least importance to 'improves service quality' as an important benefit of electronic banking. Efforts should also be made to improve the perceptions of electronic banking. Otherwise, bank employees may not be persuasive and can transfer the negative perceptions to customers (Bowen et al., (1999). Senior bankers, especially branch managers, have the ability to influence their staff, and this should be exploited. Individual banks could conduct in-house research in order to develop more targeted strategies for action (Lymperopoulos and Chaniotakis, 2004).

Table 6 presents the bankers' perceptions of the risks associated with electronic banking. The results show some interesting insights. Bankers of all categories consider 'government access to data' as the biggest risk associated with electronic banking. Interestingly, bankers show clear disagreement with most of the statements as average mean value is less than 2.5. Overall bankers disagree in general that 'heavy service charges' are an important risk except for Executives and employees of Privatized banks, who give least weight to 'chance of data losses' as a risk associated with electronic banking.

\section{Conclusion}

This study was based upon 18 potential attributes identified in the literature review and covering the benefits and risks associated with electronic banking. Using these attributes, 
the study investigated banks employees' perceptions of electronic banking. The study also examines whether these attributes vary in relation to the personal characteristics of respondents.

In the first process of analysis, mean scores of benefits and risks associated with electronic banking were computed and ranked. Bankers consider 'minimizes inconvenience', 'minimizes cost of transactions' and 'time saving' to be important benefits and 'chances of government access', 'chances of fraud' and 'lack of information security' to be vital risks associated with electronic banking. The bankers do not consider 'reduction in HR requirements' and 'improves service quality' to be important benefits and 'legal and security issues' and 'charging high costs for services' to be important risks associated with electronic banking.

At a further level of analysis, personal characteristics of the respondents (such as experience, position hold, qualification and type of bank currently serve) were used as parameters to identify different segments of the employees according to their perceptions relating to the importance of each attribute. The findings conclude that 'minimizes inconvenience' and 'government access to data' appear as most important benefit and risk respectively, while 'reduces HR requirements' and 'charges high costs for services' are the least important benefits and risk associated with electronic banking.

\section{References}

Aladwani, A.M. (2001), "Online banking: a field study of drivers, development challenges, and expectations", International Journal of Information Management, Vol. 21 No.3, pp. 213-25

Barnes, J.G., Howlett, D. M. (1998), "Predictors of equity in relationships between financial services providers and retail customers", International Journal of Bank Marketing, Vol. 16 pp.15-23.

Berry, L.L. (1984), "The employee as customer", in Lovelock, C. (Eds), Services Marketing, Kent Publishing, Boston, MA, pp.271-8..

Bhattacherjee, A. (2002), "Individual trust in online firms: scale development and initial test", Journal of Management and Information Systems, Vol. 19 No.1, pp.211-41.

Black, N.J., Lockett, A., Winklhofer, H., Ennew, C. (2001), "The adoption of Internet financial services: a qualitative study", International Journal of Retail \& Distribution Management, Vol. 29 No.8, pp.390-8. 
Boon, O., H., and Ming, Yu, C., (2003), "Success factors in e-channels: the Malaysian banking scenario", International Journal of Bank Marketing, Vol. 21, No. 6/7, pp. 369377.

Bowen, D.E., Gilliland, S., Folger, R. (1999), "HRM and service fairness: how being fair with employees spill over to customers", Organizational Dynamics, Vol. 27 pp.723.

Bowen, D. E., Schneider, B., Kim, S. (2000), "Shaping service cultures through strategic human resource management", Handbook of Services Marketing, Sage Publications, Beverly Hills, CA, pp.439-54.

Byers, R., Lederer, P.J. (2001), "Retail bank services strategy: a model of traditional, electronic, and mixed distribution choices", Journal of Management Information Systems, Vol. 18 No.2, pp.133-56.

Cantrell, C (1997), "Up close and profitable", Bank Marketing, Vol. 29 No.6, pp.45-6.

Doney, P.M., Cannon, J.P. (1997), "An examination of the nature of trust in buyer-seller relationship", Journal of Marketing, Vol. 61 No. April, pp.35-51. European Central Bank (ECB) (1999), "The Effects of Technology in the EU Banking Systems", ECB, Frankfurt am Main, July.

Gerson, V. (1998), "Service with more than a smile'", Bank Marketing, Vol. 30 No.8, pp.32-6.

Hughes, T. (2001), "Market orientation and the response of UK financial services companies to changes in Market conditions as a result of e-commerce", International Journal of Bank Marketing, Vol. 19 No.6, pp.222-31.

Hewer, P., Howcroft, B. (1999), "Consumers distribution channel adoption and usage in the financial services industry: a review of existing approaches", Journal of Financial Services Marketing, Vol. 3 No.4, pp.344-58.

Howcroft, B., Hamilton, R., Hewer, P. (2002), "Consumer attitude and the usage and adoption of home-based banking in the United Kingdom", The International Journal of Bank Marketing, Vol. 20 No.3, pp.111-21.

Joseph, M., Sekhon, Y., Stone, G. and Tinson, J. (2005), “An exploratory study on the use of banking technology in the UK; A ranking of importance of selected technology on consumer perception of service delivery performance", International Journal of Bank Marketing, Vol. 23, No. 5, pp. 397-413. 
Jun, M., Cai, S. (2001), "The key determinants of Internet banking service quality: a content analysis", International Journal of Bank Marketing, Vol. 19 No.7, pp.276-91.

Kolachi, N. (2006), "Internet banking system in Pakistan: some crucial weaknesses and suggestions for improvement", Journal of Institute of Bankers Pakistan, Vol. 73, No. 2 , pp. $23-32$.

Larpsiri, R., Rotchanakitumnuai, S., Chaisrakeo, S., Speece, M. (2002), "The impact of Internet banking on Thai consumer perception", paper presented at the Conference on Marketing Communication Strategies in a Changing Global Environment, Hong Kong, May,

Lassar, M., W., Manolis, C. and Lassar, S., (2005), "The relationship between consumer innovativeness, personal characteristics, and online banking adoption", International Journal of Bank Marketing, Vol. 23, No. 2, pp. 176-199.

Lymperopoulos, C., and Chaniotakis, E. (2004), "Branch employees' perceptions towards implications of e-banking in Greece", International Journal of Retail \& Distribution Management, Vol. 32, No. 6, pp. 302-311.

Min, H., Galle, W.P. (1999), "Electronic commerce usage in business-to-business purchasing", International Journal of Operations \& Production Management, Vol. 19 No.9, pp.909-21.

Mols, N.P. (1999), "The Internet and the banks' strategic distribution channel decisions", International Journal of Bank Marketing, Vol. 17 No.6, pp.245-300.

Moutinho, L., Davies, F., Deng, S., Miguel P. S. and Alcaniz J. E. (1997), “The future role of bank branches and their managers: comparing managerial perceptions in Canada and Spain", International Journal of Bank Marketing, Vol. 15, No. 3, pp. 99-105.

Mukherjee, A., Nath, P. (2003), "A model of trust in online relationship banking", International Journal of Bank Marketing, Vol. 21 No.1, pp.5-15.

Nancy B., Lockett, A., Winklhofer, H., and Christine, E., (2001), "The adoption of Internet financial services: a qualitative study", International Journal of Retail \& Distribution Management, Vol. 29, No. 8, pp. 390-398.

Oumlil, A., Williams, A. (2000), "Consumer education programs for mature customers", Journal of Services Marketing, Vol. 14 No.3, pp.232-43.

Patricio, L., Fisk, R., Falcao e Cunha, J. (2003), "Improving satisfaction with bank service offerings: measuring the contribution of each delivery channel", Managing 
Service Quality, Vol. 13 No.6, pp.471-83.

Polatoglu, V.N., Ekin, S. (2001), "An empirical investigation of the Turkish consumers' acceptance of Internet banking services", International Journal of Bank Marketing, Vol. 19 No.4, pp.156-65.

Rexha, N., Philip, R., Kingshott, J. and Shang-Aw, A., S. (2003) "The impact of the relational plan on adoption of electronic banking", Journal of Services Marketing, Vol. 17, No. 1, pp. 53-67.

Robinson, G. (2000), "Bank to the future", Internet Magazine, www.findarticles.com,

Rotchanakitumnuai, S. and Speece, M.,(2003), “ Barriers to Internet banking adoption: a qualitative study among corporate customers in Thailand", International Journal of Bank Marketing, Vol. 21, No 6/7, pp. 312-323.

Sathye, M. (1999), "Adoption of Internet banking by Australian consumers: an empirical investigation", International Journal of Bank Marketing, Vol. 17 No.7, pp.324-34. State Bank of Pakistan, (2000-2006), "State Bank of Pakistan annual reports", Karachi, Pakistan.

Suganthi, B. and Balachandran, P. (2001), "Internet banking patronage: an empirical investigation of Malaysia", Journal of Internet Banking and Commerce, www.arraydev.com/commerce/JIBC, Vol. 6 No.1, .

Thornton, J., White, L. (2001), "Customer orientations and usage of financial distribution channels", Journal of Services Marketing, Vol. 15 No.3, pp.168-85.

Tyler, E., Stanley, E. (1999), "UK bank-corporate relationships: large corporate expectations of service", International Journal of Bank Marketing, Vol. 17 No.4. pp. 167-186. White, H., Nteli, F. (2004), "Internet banking in the UK: why are there not more customers?", Journal of Financial Services Marketing, Vol. 9 pp.49-57.

Yakhlef, A. (2001), "Does the Internet compete with or complement bricks-and-mortar bank branches?", International Journal of Retail \& Distribution Management, Vol. 29 No.6, pp.272-81.

Zhu, F., X., Wymer, W., Chen, I. (2002),'IT-based services and service quality in consumer banking", International Journal of Service Industry Management, Vol. 13, No. 1. pp. 69-90. 
An organization without planning is like a sailboat minus its rudder. Without planning, organizations are subject to the winds of environment charge, yet have little means to take advantage of the prevailing currents in determining their own direction. Planning is the management function that involves setting goals and deciding how best to achieve them. The function also includes what must be done to encourage necessary levels of change and innovation. Planning provides a basis for the other major functions of management - organization, leading, and controlling - by charting the course and providing the steering mechanism.

Kathryn M Bartol \& David C. Martin Management 